\title{
MAKALAH ANTROPOLOGI HUKUM
}

"TINGKAT KEBUDAYAAN"

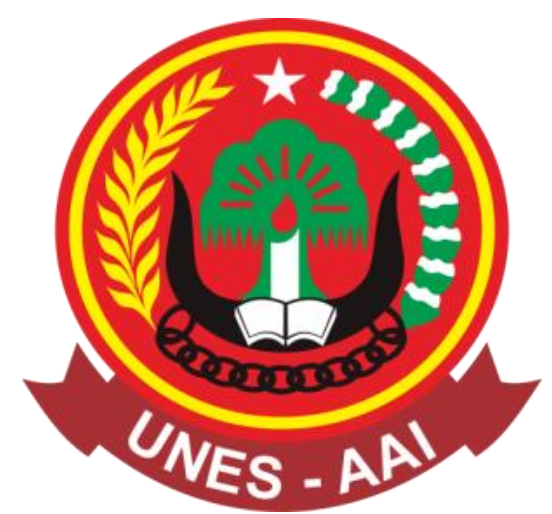

Nama : Tio Samilta

Email : tiosamilta17@gmail.com

No BP : 1810003600286

PROGRAM STUDI ILMU HUKUM

UNIVERSITAS EKASAKTI PADANG

TAHUN 2021 


\section{BAB I \\ PENDAHULUAN}

\section{A. Latar Belakang}

Manusia dalam kesehariannya tidak akan lepas dari kebudayaan, karena manusia adalah pencipta dan pengguna kebudayaan itu sendiri. Manusia hidup karena adanya kebudayaan, sementara itu kebudayaan akan terus hidup dan berkembang manakala manusia mau melestarikan kebudayaan dan bukan merusaknya. Dengan demikian manusia dan kebudayaan tidak dapat dipisahkan satu sama lain, karena dalam kehidupannya tidak mungkin tidak berurusan dengan hasil-hasil kebudayaan, setiap hari manusia melihat dan menggunakan kebudayaan.

Rasa saling menghormati dan menghargai akan tumbuh apabila antar sesama manusia menjujung tinggi kebudayaan sebagai alat pemersatu kehidupan, alat komunikasi antar sesama dan sebagai ciri khas suatu kelompok masyarakat. Kebudayaan berperan penting bagi kehidupan manusia dan menjadi alat untuk bersosialisasi dengan manusia yang lain dan pada akhirnya menjadi ciri khas suatu kelompok manusia. Manusia sebagai mahluk sosial membutuhkan alat sebagai jembatan yang menghubungkan dengan manusia yang lain yaitu kebudayaan.

Kebudayaan dapat didefinisikan sebagai suatu keseluruhan pengetahuan manusia sebagai makhluk sosial yang digunakan untuk memahami dan menginterpretasikan lingkungan dan pengalamannya, serta menjadi pedoman bagi tingkah lakunya.

Kebudayaan merupakan warisan yang tak ternilai harganya bagi bangsa ini. Kebudayaan itu harus dilestarikan, dijaga, dan dimanfaatkan. Wulandari (2011:190-191) menjelaskan bahwa kebudayaan mengandung dua kemampuan sekaligus, yaitu kemampuan untuk melestarikan dan kemampuan untuk mengembangkan. Kemampuan mempertahankan kebudayaan agar keberadaannya tetap lestari, dan kemampuan 
mengembangkan kebudayaan agar lebih berkembang dan lebih maju meskipun adanya perubahan zaman. Kemampuan tersebut akan sangat bergantung pada tingkat ketahanan budaya masyarakatnya. Semakin rendah ketahanan budaya masyarakat, semakin kuat budaya luar memengaruhi dan bahkan menghilangkannya secara perlahan-lahan.

Mempelajari kebudayaan bukanlah suatu kegiatan yang mudah dan sederhana, karena banyak sekali batasan konsep dari berbagai bahasa, sejarah, sumber bacaan atau literatur baik pendekatan metode juga telah banyak disiplin ilmu lain yang juga mengkaji berbagai macam permasalahan terkait kebudayaan seperti, Sosiologi, Psikoanalisis, Psikologi (Perilaku) dan sebagainya yang masing-masing mempunyai tingkat kejelasan sendiri-sendiri tergantung pada konsep dan penekanan masing-masing.

\section{B. Rumusan Masalah}
a. Apakah Pengertian Kebudayaan?
b. Apakah Unsur - Unsur dalam Kebudayaan?
c. Apa saja masalah yang timbul dalam kebudayaan dan solusinya ?

\section{Tujuan Penulisan}
a. Mengetahui definisi kebudayaan
b. Mengetahui apa saja unsur - unsur pembentuk kebudayaan
c. Mengetahui masalah masalah da solusi dalam kebudayaan 


\section{BAB II \\ PEMBAHASAN}

\section{A. Definisi Kebudayaan}

Kebudayaan atau yang dapat disebut juga "Peradaban" mengandung pengertian yang sangat luas dan mengandung pemahaman perasaan suatu bangsa yang sangat kompleks meliputi pengetahuan, kepercayaan, seni, moral, hukum, adat-istiadat, kebiasaan dan pembawaan lainnya yang diperoleh dari anggota masyarakat. (Taylor, 1897). Kebudayaan didefinisikan sebagai keseluruhan pengetahuan manusia sebagai makhluk sosial yang digunakannya untuk memahami dan menginterprestasikan lingkungan dan pengalamanya, serta menjadi landasan bagi tingkah-lakunya. Dengan demikian, kebudayaan merupakan serangkaian aturan-aturan, petunjuk-petunjuk, rencana-rencana, dan strategi-strategi yang terdiri atas serangkaian model-model kognitif yang dipunyai oleh manusia, dan digunakannya secara selektif dalam menghadapi lingkungannya sebagaimana terwujud dalam tingkah-laku dan tindakan-tindakannya.

Apabila ditinjau dari asal katanya, maka "Kebudayaan" berasal dari bahasa Sanskerta yaitu "Budhayah", yang merupakan bentuk jamak dari "Budhie yang berarti

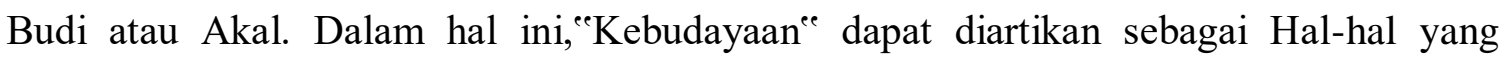
bersangkutan dengan budi atau akal. Dalam disiplin Ilmu Antropologi Budaya, pengertian Kebudayaan dan Budaya tidak dibedakan. Adapun pengertian Kebudayaan dalam kaitannya dengan Ilmu Sosial Budaya Dasar (ISBD) adalah : "Penciptaan, penertiban dan pengolahan nilai-nilai insani yang tercakup di dalamnya usaha memanusiakan diri di dalam alam lingkungan, baik fisik maupun sosial”. Manusia memanusiakan dirinya dan memanusiakan lingkungannya.

Sebagai pengetahuan, kebudayaan adalah suatu satuan ide yang ada dalam kepala manusia dan bukan suatu gejala (yang terdiri atas kelakuan dan hasil kelakuan manusia). 
Sebagai satuan ide, kebudayaan terdiri atas serangkaian nilai-nilai, norma-norma yang berisikan larangan-larangan untuk melakukan suatu tindakan dalam menghadapi suatu lingkungan sosial, kebudayaan, dan alam, serta berisi serangkaian konsep-konsep dan model-model pengetahuan mengenai berbagai tindakan dan tingkah laku yang seharusnya diwujudkan oleh pendukungnya dalam menghadapi suatu lingkungan sosial, kebudayaan, dan alam. Jadi nilai-nilai tersebut dalam penggunaannya adalah selektif sesuai dengan lingkungan yang dihadapi oleh pendukungnya.

Dari berbagai sisi, kebudayaan dapat dipdang sebagai: (1) Pengetahuan yang diyakini kebenarannya oleh masyarakat yang memiliki kebudayaan tersebut; (2) Kebudayaan adalah milik masyarakat manusia, bukan daerah atau tempat yang mempunyai kebudayaan tetapi manusialah yang mempunyai kebudayaan; (3) Sebagai pengetahuan yang diyakini kebenarannya, kebudayaan adalah pedoman menyeluruh yang mendalam dan mendasar bagi kehidupan masyarakat yang bersangkutan; (4) Sebagai pedoman bagi kehidupan, kebudayaan dibedakan dari kelakuan dan hasil kelakuan; karena kelakuan itu terwujud dengan mengacu atau berpedoman pada kebudayaan yang dipunyai oleh pelaku yang bersangkutan.

\section{B. Unsur-Unsur Kebudayaan}

Unsur kebudayaan terdiri atas :

1. System regili dan upacaru keagamaan merupakan produk manusia sebagai homoriligius. manusia yang mempunyai kecerdasan, pikiran, dan perasaan luhur, tangapan bahwa kekuatan lain mahabesar yang dapat "menghitam-putikan" kehidupannya.

2. System organisasi kemasyarakatan merupakan produk manusia sebagAi homosocius. Manusia sadar bahwa tubuh nya lemah. Namun, dengan akalnya manusia membuat 
kekuatan dengan menyusun organisasi kemasyarakatan yang merupakan tempat berkerja sama untuk mencapai tujuan baersama, yaitu meningatkan kesejahtraan hidupnya.

3. System mata pencarian yang merupakan produk dari manusia sebagai homoeconomicus manjadikan tinkat kehudupan manusia secara umum terus meningkat. Contoh bercocok tanam, kemudian berternak, lalu mengusahakan kerjinan, dan berdagang.

Kebudayaan dapat dibagi menjadi 3 macam dilihat dari keadaan jenis-jenisnya:

- Hidup-kebatinan manusia, yaitu sesuatu yang menimbulkan tertib damainya hidup masyarakat dengan adat-istiadatnya,pemerintahan negeri, agama atau ilmu kebatinan

- Angan-angan manusia, yaitu sesuatu yang dapat menimbulkan keluhuran bahasa, kesusasteraan dan kesusilaan.

- Kepandaian manusia, yaitu sesuatu yang menimbulkan macam-macam kepandaian tentang perusahaan tanah, perniagaan, kerajinan, pelayaran, hubungan lalu-lintas, kesenian yang berjenis-jenis; semuanya bersifat indah (Dewantara; 1994).

Kebudayaan berdasarkan wujudnya :

Menurut J.J. Hoenigman, wujud kebudayaan dibedakan menjadi tiga,yaitu:

\section{- Gagasan (Wujud ideal)}

Wujud ideal kebudayaan adalah kebudayaan yang berbentuk kumpulan ide-ide, gagasan, nilai-nilai, norma-norma, peraturan, dan sebagainya yang sifatnya abstrak; tidak dapat diraba atau disentuh. Wujud kebudayaan ini terletak dalam kepala-kepala atau di alam pemikiran warga masyarakat. Jika masyarakat tersebut menyatakan gagasan mereka itu dalam bentuk tulisan, maka lokasi dari kebudayaan ideal itu 
berada dalam karangan dan buku-buku hasil karya para penulis warga masyarakat tersebut.

\section{- Aktivitas (tindakan)}

Aktivitas adalah wujud kebudayaan sebagai suatu tindakan berpola dari manusia dalam masyarakat itu. Wujud ini sering pula disebut dengan sistem sosial. Sistem sosial ini terdiri dari aktivitas-aktivitas manusia yang saling berinteraksi, mengadakan kontak, serta bergaul dengan manusia lainnya menurut pola-pola tertentu yang berdasarkan adat tata kelakuan. Sifatnya konkret, terjadi dalam kehidupan sehari-hari, dan dapat diamati dan didokumentasikan.

\section{- Artefak (karya)}

Artefak adalah wujud kebudayaan fisik yang berupa hasil dari aktivitas, perbuatan, dan karya semua manusia dalam masyarakat berupa benda-benda atau hal-hal yang dapat diraba, dilihat, dan didokumentasikan. Sifatnya paling konkret diantara ketiga wujud kebudayaan.

Berdasarkan wujudnya tersebut, kebudayaan dapat digolongkan atas dua komponen utama:

\section{- Kebudayaan material}

Kebudayaan material adalah kebudayaan yang mengacu pada semua ciptaan masyarakat yang nyata, konkret. Contoh kebudayaan material ini adalah temuantemuan yang dihasilkan dari suatu penggalian arkeologi: mangkuk tanah liat, perhisalan, senjata, dan seterusnya. Kebudayaan material juga mencakup barangbarang, seperti televisi, pesawat terbang, stadion olahraga, pakaian, gedung pencakar langit, dan mesin cuci. 


\section{- Kebudayaan nonmaterial}

Kebudayaan nonmaterial adalah ciptaan-ciptaan abstrak yang diwariskan dari generasi ke generasi, misalnya dongeng, cerita rakyat, dan lagu atau tarian tradisional.

Kebudayaan secara umum dapat dibagi menjadi dua macam yaitu :

a. Kebudayaan Daerah adalah kebudayaan dalam wilayah atau daerah tertentu yang diwariskan secara turun temurun oleh generasi terdahulu pada generasi berikutnya pada ruang lingkup daerah tersebut. Budaya daerah ini muncul saat penduduk suatu daerah telah memiliki pola pikir dan kehidupan sosial yang sama sehingga itu menjadi suatu kebiasaan yang membedakan mereka dengan penduduk - penduduk yang lain. Budaya daerah mulai terlihat berkembang di Indonesia pada zaman kerajaan kerajaan terdahulu. Hal itu dapat dilihat dari cara hidup dan interaksi sosial yang dilakukan masing-masing masyarakat kerajaan di Indonesia yang berbeda satu sama lain.

Dari pola kegiatan ekonomi kebudayaan daerah dikelompokan beberapa macam yaitu:

- Kebudayaan Pemburu dan Peramu

Kelompok kebudayaan pemburu dan peramu ini pada masa sekarang hampir tidak ada. Kelompok ini sekarang tinggal di daerah-daerah terpencil saja.

- Kebudayaan Peternak

Kelompok kebudayaan peternak/kebudayaan berpindah-pindah banyak dijumpai di daerah padang rumput.

- Kebudayaan Peladang

Kelompok kebudayaan peladang ini hidup di daerah hutan rimba. Mereka menebang pohon-pohon, membakar ranting, daun-daun dan dahan yang ditebang. Setelah bersih 
lalu ditanami berbagai macam tanaman pangan. Setelah dua atua tiga kali ditanami, kemudian ditinggalkan untuk membuka ladang baru di daerah lain.

- Kebudayaan Nelayan

Kelompok kebudayaan nelayan ini hidup di sepanjang pantai. Desa-desa nelayan umumnya terdapat di daerah muara sungai atau teluk. Kebudayaan nelayan ditandai kemampuan teknologi pembuatan kapal, pengetahuan cara-cara berlayar di laut, pembagian kerja nelayan laut.

- Kebudayaan Petani Pedesaan

Kelompok kebudayaan petani pedesaan ini menduduki bagian terbesar di dunia. Masyarakat petani ini merupakan kesatuan ekonomi, sosial budaya dan administratif yang besar. Sikap hidup gotong royong mewarnai kebudayaan petani pedesaan.

Kebudayaan Nasional adalah gabungan dari budaya daerah yang ada di Negara tersebut.Itu dimaksudkan budaya daerah yang mengalami asimilasi dan akulturasi dengan dareah lain di suatu Negara akan terus tumbuh dan berkembang menjadi kebiasaan-kebiasaan dari Negara tersebut.

\section{Masalah yang Timbul dalam Kebudayaan dan Solusinya}

Kebudayaan adalah hasil cipta, rasa dan karsa dari manusia oleh karena itu kebudayaan akan mengalami perubahan dan perkembangan sejalan dengan perkembangan dan pola pikir manusia. Di Indonesia terdapat bermacam - macam suku, ras, kepercayaan dan budaya. Setiap daerah memiliki kebudayaan masing - masing, dan suatu kebudayaan merupakan ciri khas daerah atau kelompok tertentu. Kebudayaan ini menyebabkan adanya perbedaan norma- norma, tingkah laku, kepercayaan, adat istiadat dan sebagainya antara kelompok yang satu dan kelompok lainya. Dengan berkembangnya ilmu pengetahuan dan teknologi modern, mudahnya akses tentang 
kebudayaan barat disertai dengan pengetahuan dan pola pikir masyarakat (kelompok tertentu) yang masih rendah maka dengan mudahnya kelompok tertentu akan menerapkan kebudayaan asing dalam kehidupanya sehari - hari.

Ketidakmampuan sebagian masyarakat Indonesia untuk beradaptasi dengan kebuadayaan barat berakibat pada pergeseran budaya, etika dan moral di Indonesia. Karena ingin mendapat pengakuan sebagai masyarakat yang modern, maka masyarakat Indonesia banyak yang mengikuti gaya hidup dan berbagai budaya barat tanpa di filterisasi, sehingga seringkali mengabaikan budaya di Tanah Air. Sesungguhnya inti permasalahanya bukan pada kesalahan dari budaya barat yang masuk ke Indonesia tapi bagaimana seharusnya sebagai manusia menghargai budaya kita sendiri.

Adapun beberapa permasalahan yang dihadapi oleh bangsa Indonesia dalam menjaga dan melestarikan kebudayaannya yaitu :

1. Semakin Kompleksnya Kebutuhan dan Masalah yang dihadapi oleh manusia Manusia memiliki kebutuhan hidup yang tak terbatas. Oleh sebab itu manusia akan melakukan segala hal untuk memenuhi kebutuhanya tersebut. Inilah salah satu hal yang melatarbelakangi pertukaran budaya antara kelompok yang satu dengan yang lainya. Karena kebutuhan yang tak terbatas dan sarana pemenuhan kebutuhan yang terbatas menyebaban orang akan mencari alat pemenuh kebutuhan tersebut di tempat atau kelompok lain. Pada saat Ia telah mendapatkan sedikit kepuasan di tempat lain yang memiliki kebudayaan berbeda, maka ketika Ia berkeluarga dan tinggal jauh dari tempat asalnya, anak yang lahir dari keluarga tersebut kemungkinan besar tidak akan mengetahui adat istiadat dan kebudayaan orang tuanya. Hal ini akan terjadi ke genersai - generasi berikutnya, sehingga kebudayaan asalnya akan mulai terlupakan. 
2. Kurangnya Pendidikan tentang Budaya

Kecintaan akan budaya lokal harus ditanamkan sejak dini, agar ketika seorang anak tumbuh besar Ia tidak akan merasa asing atau minder atau kuno dengan kebudayaan yang Ia miliki. Saat ini di Sekolah - sekolah Indonesia sangat jarang sekali ada mata pelajaran yang mempelajari dan mempraktekkan tentang budaya - budaya yang ada di Indonesia. Pemerintah bisa mempertimbangkan agar anak - anak sekolah bisa mendapat pelajaran budaya, misalnya tentang bahasa dan kesenian daerah - daerah di Indonesia.

\section{Pengaruh Perkembangan Teknologi}

Mudahnya akses terhadap kebudayaan luar dan gencarnya media elektronik dan media cetak "mempromosikan" kebudayaan barat menyebabkan semakin mendominasinya kebudayaan barat dari pada kebudayaan lokal. Misalnya kaum muda saat ini lebih menggandrungi film - film barat dibandingkan film lokal, menjamurnya tempat kuliner barat, dan perubahan gaya hidup masyarakat Indonesia seperti : lebih sering belanja ke mall - mall di luar negeri, mengenakan pakaian terbuka yang sebenarnya tidak sesuai dengan budaya timur. Perilaku tersebut mengakibatkan kebudayaan lokal menjadi terlupakan.

4. Peran serta Pemerintah dan masyarakat

Kelestarian kebudayaan Bangsa menjadi tanggung jawab kita bersama, baik pemerintah maupun masyarakat. Kita semua harus menjaga kebudayaan yang merupakan jati diri Bangsa Indonesia. Seperti beberapa kasus yang telah terjadi di Negara kita. Banyak kebudayaan kita yang di klaim oleh Negara lain sebagai kebudayaan dari Negaranya. 


\section{BAB III \\ PENUTUP}

\section{A. Kesimpulan}

Kebudayaan merupakan pengetahuan yang merupakan system ide atau gagasan yang terdapat dalam pikiran manusia. Perwujudan kebudayaan diciptakan manusia sebagai makhluk yang berbudaya, berupa prilaku dan benda-benda yang bersifat nyata. Kebudayaan dimiliki oleh setiap manusia, kebudayaan membentuk karakter manusia dalam tindakan- tindakan yang dilakukan sehari-hari. Setiap Negara memiliki kebudayaan yang berbeda-beda. Seiring dengan berjalannya waktu, di era globalisasi dan kemajuan teknologi seperti saat ini tidak dipungkiri masuk juga kebudayaan asing sehingga terjadi interaksi antara berbagai kebudayaan. Dimana budaya asli berinteraksi dengan budaya asing yang makin berkembang dari Negara lain. Interaksi tersebut menciptakan Hubungan yang terwujud dalam bentuk akulturasi, asimilasi, sintesis dan penetrasi. Masuknya budaya asing dan hubungan antar budaya tersebut tentu akan menciptakan dampak yang bersifat positif dan negative.

\section{B. Saran}

Adapun saran yang ingin penyusun sampaikan kepada pembaca adalah agar makalah ini dapat menambah pengetahuan lagi mengenai kebudayaan Indonesia. Selain itu, diharapkan juga agar para pembaca dapat mengenal atau mengetahui kebudayaan yang ada di Indonesia. Sehingga, kita dapat bersama-sama melestarikan budaya Indonesia yang ada. Agar kita tidak lebih banyak lagi kehilangan budaya kita. 


\section{DAFTAR PUSTAKA}

Gokma Toni Parlindungan S, Asas Nebis In Idem Dalam Putusan Hakim Dalam Perkara Poligami Di Pengadilan Negeri Pasaman Sebagai Ceriminan Ius Constitutum, Volume 2, Nomor 1, 2020.

Gokma Toni Parlindungan S, Pengisian Jabatan Perangkat Nagari Pemekaran Di Pasaman Barat Dalam Rangka Pelaksanaan Otonomi Daerah, Ensiklopedia Of Journal, Vol 1 No 2 Edisi 2 Januari 2019,

Harniwati, Peralihan Hak Ulayat Menurut Undang-Undang Nomor 18 Tahun 2004, Volume 1, Nomor 3, 2019.

Jasmir, Pengembalian Status Hukum Tanah Ulayat Atas Hak Guna Usaha, Soumatera Law Review, Volume 1, Nomor 1, 2018.

Jumrawarsi Jumrawarsi, Neviyarni Suhaili, Peran Seorang Guru Dalam Menciptakan Lingkungan Belajar Yang Kondusif, Ensikopedia Education Review, Vol 2, No 3 (2020): Volume 2 No.3 Desember 2020

Mia Siratni, Proses Perkawinan Menurut Hukum Adatdi Kepulauan Mentawai Di Sebelum Dan Sesudah Berlakunya Undang-Undang Nomor 1 Tahun 1974 Tentang Perkawinan, Ensiklopedia Of Journal, Vol 1 No 2 Edisi 2 Januari 2019,

Remincel, Dimensi Hukum Pelanggaran Kecelakaan Lalu Dan Angkutan Jalan Lintas Di Indonesia, Ensiklopedia Social Review, Volume 1, Nomor 2, 2019.

R Amin, B Nurdin, Konflik Perwakafan Tanah Muhammadiyah di Nagari Singkarak Kabupaten Solok Indonesia 2015-2019, Soumatera Law Review, Volume 3, Nomor 1, 2020. 